\title{
Clinical Significance of Cardiac Permanent Pacemaker Mode Option in Patients with Complete Atrioventricular Block
}

\section{Atriyoventriküler Tam Bloklu Hastalarda Kalıcı Kalp Pili Mod Seçiminin Klinik Önemi}

\section{(D) Orhan İnce ${ }^{1}$, (D Kamil Gülşen², (D Sevgi Özcan¹, (D) Ertuğrul Okuyan¹, (D Cengiz Çeliker³}

${ }^{1}$ University of Health Sciences Turkey, İstanbul Bağcılar Training and Research Hospital, Clinic of Cardiology, İstanbul, Turkey

${ }^{2}$ Kartal Koşuyolu Yüksek İhtisas Training and Research Hospital, Clinic of Cardiology, İstanbul, Turkey

3̇̀stanbul University Cerrahpaşa Cardiology Institute, Clinic of Cardiology, İstanbul, Turkey

\section{Abstract}

Objective: We assessed the impact of pacing mode on long-term clinical outcomes in cases with the complete atrioventricular block (CAB).

Method: We retrospectively analyzed 161 patients with $C A B$, who undergone a cardiac permanent pacemaker. Of the patients involved in the physiologic pacing (PP) group, 95 patients were with the VDD pacing mode and 14 patients were with the DDD pacing mode. In the ventricular pacing (VP) group, with the VVI pacing mode, there were 52 patients.

Results: The average age of the patients was $66 \pm 13$ years and the average follow-up duration was $40.2 \pm 22.6$ months. Atrial fibrillation (AF) was observed to be significantly more common in the VP group than in the PP group ( $p=0.007)$. However, the occurrence of stroke was similar between the two groups $(p=0.753)$. Newly developed congestive heart failure (CHF) was seen more commonly in the VP group $(p=0.015)$. When we evaluated the patients with and without $\mathrm{CHF}$ before pacemaker placement, the number of patients with $\mathrm{CHF}$ was reduced in the PP group $(p=0.039)$ and insignificantly increased in the VP group $(p=0.219)$.

Conclusion: We conclude that in patients with $C A B$, the use of $P P$, compared to $\mathrm{VP}$, may decrease the rate of $\mathrm{AF}$ and $\mathrm{CHF}$ in the long-term.

Keywords: Artificial cardiac pacing, atrial fibrillation, atrioventricular block, heart failure, stroke

\section{Öz}

Amaç: Atriyoventriküler (AV) tam bloklu hastalarda kalıcı pacemaker mod seçiminin uzun dönem klinik sonuçları incelendi.

Yöntem: AV tam blok nedeni ile kalıcı pacemaker takılan toplam 161 hasta retrospektif olarak incelendi. Fizyolojik pacemaker (FP) grubu altında incelenen hastaların 95'inde VDD, 14'ünde DDD modu bulunmaktaydı. Ventriküler pacemaker (VP) grubu içinde incelenen 52 hastada VVI modu mevcuttu.

Bulgular: Ortalama yaş $66 \pm 13$ yıl ve ortalama takip süresi $40,2 \pm 22,6$ ay idi. Takip süresinde, VP grubunda, FP grubu ile karşılaştıııldığında daha fazla oranda atriyal fibrilasyon (AF) saptandı $(p=0,007)$. İnme gelişimi açısından iki grup arasında bir fark bulunmadı $(p=0,753)$. Pacemaker takılmadan önce konjestif kalp yetersizliği (KKY) bulunmayan hastalar incelendiğinde, takip süresi esnasında VP grubunda daha fazla oranda KKY gelişimi tespit edildi $(p=0,015)$. Başlangıçta $K K Y$ bulunan ve bulunmayan hastalar birlikte incelendiğinde, takip süresi sonunda FP'li grupta KKY bulunan hastaların sayısı azalırken $(p=0,039)$, VP'li grupta istatistiksel olarak anlamlı olmayan düzeyde bir artma saptandı $(p=0,219)$.

Sonuç: AV tam bloklu hastalarda FP kullanımı, VP kullanımı ile karşılaştııılığında, uzun dönemde AF ve KKY gelişimini azaltabilir.

Anahtar kelimeler: Atriyal fibrilasyon, atriyoventriküler blok, inme, kalp yetersizliği, yapay kalp pili

Address for Correspondence: Orhan İnce, University of Health Sciences Turkey, İstanbul Bağcılar Training and Research Hospital,

E-mail: drorhanince@gmail.com ORCID: orcid.org/0000-0001-6413-6407 Received: 11.05.2020 Accepted: 03.06.2020

Cite this article as: Ince O, Gülşen K, Özcan S, Okuyan E, Çeliker C. Clinical Significance of Cardiac Permanent Pacemaker Mode Option in Patients with Complete Atrioventricular Block. Bagcilar Med Bull 2020;5(4):148-151

${ }^{\circ}$ Copyright 2020 by the Health Sciences University Turkey, Bagcilar Training and Research Hospital Bagcilar Medical Bulletin published by Galenos Publishing House. 


\section{Introduction}

Physiologic pacing (PP) possibly provides a clinical benefit compared to ventricular pacing (VP) in the treatment of the complete atrioventricular block (CAB). Non-randomized studies suggest that $\mathrm{PP}$ is associated with a lesser incidence of stroke, atrial fibrillation (AF), heart failure than in the VP, and mortality decreases in patients with heart failure (18). Mortality rates were found similar between two groups in a recent retrospective study (9). The small randomized studies comparing PP to VP have demonstrated that mortality, the incidence of AF, and stroke are high in VP $(10,11)$. For mortality and heart failure, the randomized studies with more patients established no significant differences between the PP and VP groups (12-14). For AF, only the Canadian Trial of Physiologic Pacing (CTOPP) found a risk reduction in the PP group (12), and for stroke, only the United Kingdom Pacing and Cardiovascular Events (UKPACE) trial found risk increase in the fixed-rate VP group (13).

\section{Materials and Methods}

All patients who received a cardiac permanent pacemaker (CPP) for $\mathrm{CAB}$ at our institution before June 2015 were reviewed. Patients with permanent AF, missing or inadequate records, follow-up period shorter than 6 months, and younger age group ( $<20$ years) were excluded from the study.

The study group consisted of 161 patients (57\% females), $68 \%$ with PP and $32 \%$ with VP. The mean age was $66 \pm 13$ years and the mean follow-up period was $40.2 \pm 22.6$ months. The follow-up visits occurred 1, 3, and 6 months after pacemaker implantation, and there were yearly visits thereafter. The patient's clinical condition, ambulatory ECG recordings, and 12-lead ECG records were analyzed. Stroke, AF, signs and symptoms of CHF before and after pacemaker implantation were evaluated. Hemorrhagic stroke and transient ischemic attack were not included in the stroke group. Patients with paroxysmal, persistent and permanent AF during the follow-up period were involved in the AF group.

\section{Statistical Analysis}

The results are specified as mean \pm standard deviation. Statistical tests included chi-square analysis with the Yates' correction, Fisher's Exact test or McNemar test where pertinent, and Student's t-test. A p-value $<0.05$ was assessed as significant. All statistical studies were performed using SPSS for Windows, Version 9.0 (SPSS Inc., Chicago, IL, USA).

\section{Results}

No statistically significant difference was found compared to baseline characteristics between the treatment groups (Table 1).

As shown in Table 2, AF developed significantly more frequently in patients assigned to the VP group than in the PP group (34.6 vs $14.7 \%, \mathrm{p}=0.007$ ), and no significant difference existed among the patient groups concerning stroke ( $1.9 \%$ in VP vs $2.7 \%$ in PP group, $\mathrm{p}=0.753$ ).

There were five patients with a history of CHF in the VP group and 13 patients in the PP group. We excluded these patients from analysis when we compared the newly developed CHF between the groups. This study demonstrates that the newly developed CHF in the group of VP is significantly more common than among those with PP $(10.6 \%$ vs $1 \%, p=0.015$, Table 3$)$. Also, when we examined all patients with or without CHF before implantation of the pacemaker, CHF frequency was decreased significantly in

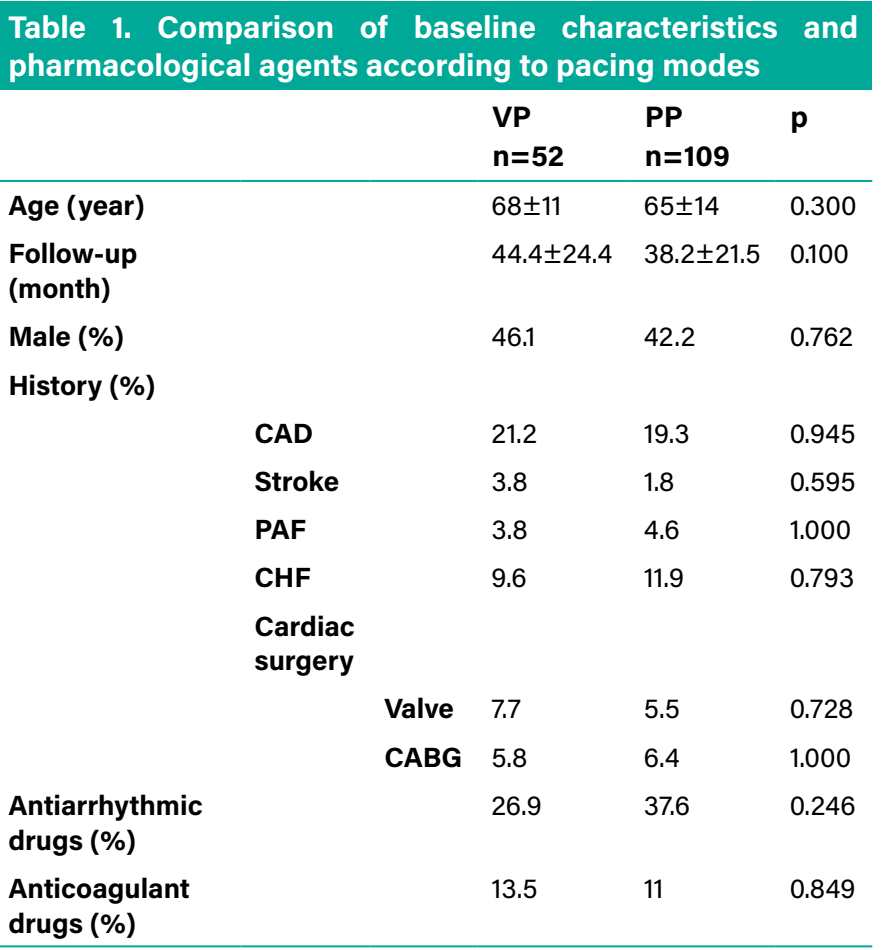

CAD: Coronary artery disease, CHF: Congestive heart failure, PAF: Paroxysmal atrial fibrillation, PP: Physiologic pacing, VP: Ventricular pacing

\begin{tabular}{|c|c|c|c|}
\hline & $\begin{array}{l}\text { VP } \\
(n=52)\end{array}$ & $\begin{array}{l}\text { PP } \\
(n=109)\end{array}$ & p \\
\hline Atrial fibrillation & $18(34.6 \%)$ & $16(14.7 \%)$ & 0.007 \\
\hline Ischemic stroke & $1(1.9 \%)$ & $3(2.7 \%)$ & 0.753 \\
\hline
\end{tabular}

PP: Physiologic pacing, VP: Ventricular pacing 
the PP group ( $\mathrm{p}=0.039)$, and insignificantly increased in the VP group ( $\mathrm{p}=0.219$ ) during the study period (Table 4 ).

\section{Discussion}

This study aimed to assess if the pacing mode, whether PP or VP, contributed to the clinical benefit in the patients with $\mathrm{CAB}$ and implanted CPP. The retrospective studies showed mortality decrease in patients with heart failure, and improved clinical outcomes with respect to AF, stroke, and heart failure with PP. The small randomized studies have shown that the mortality, incidence of $\mathrm{AF}$, and stroke were higher in the VP group. The randomized studies with more patients have failed to reveal a marked benefit for PP in terms of reduction of mortality and heart failure. AF risk was significantly lower in the PP group only in the CTOPP trial, and stroke risk was significantly higher in the fixedrate VP group only in the UKPACE trial.

$\mathrm{PP}$ is believed to have an advantage over VP in that it mimics cardiac physiology more similarly by preserving atrioventricular synchrony and domination of sinus node (15-17), increases cardiac output which in turn may reduce heart failure, AF and stroke. PP improved left ventricular functions and hemodynamics, especially in patients with heart failure (18-23). VP may induce AF through changes in the atrial structure resulting from asynchronous ventricular contraction (19).

Our results showed a high incidence of AF in the VP group like that found in the CTOPP trial. Also, we found a high incidence of $\mathrm{CHF}$ in the VP group. This may be because of the loss of AV synchronization and decreased contribution of the atrium to ventricular filling. We found no significant difference concerning stroke between the two groups.

Table 3. Newly developed congestive heart failure

\begin{tabular}{llll} 
& $\begin{array}{l}\text { VP } \\
(\mathbf{n}=47)\end{array}$ & $\begin{array}{l}\text { PP } \\
(\mathbf{n}=96)\end{array}$ & $\mathbf{p}$ \\
\hline New onset of CHF & $5(10.6 \%)$ & $1(1 \%)$ & 0.015 \\
\hline
\end{tabular}

CHF: Congestive heart failure, PP: Physiologic pacing, VP: Ventricular pacing

Table 4. The number of the patients with CHF before pacemaker implantation and at the end of follow-up period

\begin{tabular}{llll} 
& $\begin{array}{l}\text { Before pacemaker } \\
\text { implantation } \\
\text { (CHF) }\end{array}$ & $\begin{array}{l}\text { End of follow-up } \\
\text { period (CHF) }\end{array}$ & $\mathbf{p ~}$ \\
\hline VP $(\mathbf{n = 5 2 )}$ & $5(9.6 \%)$ & $9(17.3 \%)$ & 0.219 \\
PP $(\mathbf{n = 1 0 9 )}$ & $13(11.9 \%)$ & $6(5.5 \%)$ & 0.039 \\
\hline
\end{tabular}

CHF: Congestive heart failure, PP: Physiologic pacing, VP: Ventricular pacing

\section{Study Limitations}

The major limitations of our study are the small sampling size, retrospective design, although statistically insignificant, some baseline differences between the study groups.

\section{Conclusion}

We concluded that the PP compared to VP might reduce the incidence of AF and CHF. More randomized studies must be done for the selection of the best pacing mode in the patients with $\mathrm{CAB}$.

\section{Ethics}

Ethics Committee Approval: The study protocol was approved by the local ethics committee of our institution (2020.09.1.05.122).

Informed Consent: Written informed consent was obtained.

Peer-review: Externally peer-reviewed.

\section{Authorship Contributions}

Concept: C.Ç., O.İ., Design: C.Ç., O.İ., Data Collection or Processing: C.Ç., O.İ., Analysis or Interpretation: O.İ., K.G., E.O., S.Ö., Literature Search: O.İ., K.G., E.O., S.Ö., Writing: O.İ., K.G., S.Ö.

Conflict of Interest: No conflict of interest was declared by the authors.

Financial Disclosure: The authors declared that this study has received no financial support.

\section{References}

1. Linde-Edelstam C, Gullberg B, Norlander R, Pehrsson SK, Rosenqvist M, Rydén L. Longevity in patients with high degree atrioventricular block paced in the atrial synchronous or the fixed rate ventricular inhibited mode. PACE 1992;15(3):304-313.

2. Alpert MA, Curtis JJ, Sanfelippo JF, Flaker GC, Walls JT, Mukerji $\mathrm{V}$, et al. Comperative survival after permanent ventricular and dual chamber pacing for patients with chronic high degree atrioventricular block with and without preexistent congestive heart failure. J Am Coll Cardiol 1986;7(4):925-932.

3. Ebagosti A, Gueunoun M, Saadjian A, Dolla E, Gabriel M, Levy S, et al. Long-term follow-up of patients treated with VVI pacing and sequential pacing with reference to VA retrograde conduction. PACE 1988;11(11):1929-1934.

4. Langenfeld H, Grimm W, Maish B, KochsiekK. Atrial fibrillation and embolic complications in paced patients. PACE 1988;11(11):16671672 .

5. Feuer JM, Shandling AH, Mesenger JC. Influence of cardiac pacing mode on the long-term development of atrial fibrillation. Am J Cardiol 1989;64(19):1376-1379. 
6. Said S, Alkhateeb H, Cooper CJ, Gosavi S, Dwivedi A, Paez D, et al. Incidence of new onset atrial fibrillation in patients with permanent pacemakers and the relation to the pacing mode. Med Sci Monit 2014;20:268-273.

7. MatusikP, Woznica N, Lelakowsk J. Atrial fibrillation before and after pacemaker implantation (WI and DDD) in patients with complete atrioventricular block. Pol Merkur Lekarski 2010;28(167):345-349.

8. Kato Y, Hayashi T, Kato R, Tanahashi N, Takao M. Ischemic Stroke with Cardiac Pacemaker Implantation: Comparison of Physiological and Ventricular Pacing Modes. J Stroke Cerebrovasc Dis 2017;26(9):1948-1952.

9. Yamaguchi T, Miyamoto T, Iwai T, Yamaguchi J, Hijikata S, Miyazaki $\mathrm{R}$, et al. Prognosis of super-elderly healthy Japanese patients after pacemaker implantation for bradycardia. J Cardiol 2017;70(1):1822.

10. Mattioli AV, Castellani ET, Vivoli D, Sgura FA, Mattioli G. Prevalence of atrial fibrillation and stroke in paced patients without prior atrial fibrillation: A prospective study. Clin Cardiol 1998;21(2):117-122.

11. Krzemień-Wolska K, Tomasik A, Wojciechowska C, Bara skaPawełczak K, Nowalany-Kozielska E, Jache W. Prognostic Factors in Patients with an Implanted Pacemaker after 80 Years of Age in a 4-Year Follow-Up. Gerontology 2018;64(2):107-117.

12. Connolly SJ, Kerr CR, Gent M, Roberts RS, Yusuf S, Gilli AM, et al, for the Canadian Trial of Physiologic Pacing Investigators. Effects of physiologic pacing versus ventricular pacing on the risk of stroke and death due to cardiovascular causes. N Eng J Med 2000;342(19):1385-1391.

13. Toff WD, Camm AJ, Skehan JD. Single-Chamber versus DualChamber Pacing for High-Grade Atrioventricular Block. N Engl J Med 2005;353(2):145-155.

14. Lamas GA, Orav EJ, Stambler BS, Ellenbogen KA, Sgarbossa EB, Huang S, et al. Quality of life and clinical outcomes in elderly patients treated with ventricular pacing compared with dualchamber pacing. Pacemaker Selection in the Elderly Investigators. N Engl J Med 1998;338(16):1097-1104.

15. Stewart WJ, Dicola VC, Harthorne JW, Gillam LD, Weyman AE. Doppler ultrasound measurement of cardiac output in patients with physiologic pacemakers. Effects of left ventricular function and retrograde ventriculoatrial conduction. Am J Cardiol 1984;54(3):308-312.

16. Nitsch J, Seidere M, Bull U, Luderitz B. Evaluation of ventricular performance by radionuclide ventriculography in patients with atrioventricular versus ventricular demand pacemakers. Am Heart J 1984;107(5):906-911.

17. Mukharji J, Rehr RB, Hastillo A, Thomps JA, Hes ML, Paulsen WJ, et al. Comparison of atrial contribution to cardiac hemodynamics in patients with normal and severely compromised cardiac function. J Clin Cardiol 1990;13(9):639-643.

18. Gold MR, Brockman R, Peters RW, Olsovsky MR, Shorofsky SR. Acute hemodynamic effects of right ventricular pacing site and pacing mode in patients with congestive heart failure secondary to either ischemic or idiopathic dilated cardiomyopathy. Am J Cardiol 2000;85(9):1106-1109.

19. Alpert MA, Curtis JJ, Sanfelippo JF, Flaker GC, Walls JT, Mukerji V, et al. Comparative survival following permanent ventricular and dual-chamber pacing for patients with chronic symptomatic sinus node dysfunction with and without congestive heart failure. Am Heart J 1987;113(4):958-965.

20. Moro E, Caprioglio F, Berton G, Marcon C, Riva U, Corbucci G, et al. DDD versus VVIR versus VVI mode in patients with indication to dual-chamber stimulation: a prospective, randomized, controlled, single-blind study. Ital Heart J 2005;6(9):728-733.

21. Naegeli B, Kurz DJ, Koller D, Straumann E, Furrer M, Maurer D, et al. Single-chamber ventricular pacing increases markers of left ventricular dysfunction compared with dual-chamber pacing. Europace 2007;9(3):194-199.

22. Ouali S, Neffeti E, Ghoul K, Hammas S, Kacem S, Gribaa R, et al. DDD versus VVIR pacing in patients, ages 70 and over, with complete heart block. Pacing Clin Electrophysiol 2010;33(5):583589 .

23. Kılıçaslan B, Vatansever Ağca F, Kılıçaslan EE, Kınay O, Tigen K, Cakır C, et al. Comparison of DDD versus VVIR pacing modes in elderly patients with atrioventricular block. Turk Kardiyol Dern Ars 2012;40(4):331-336. 